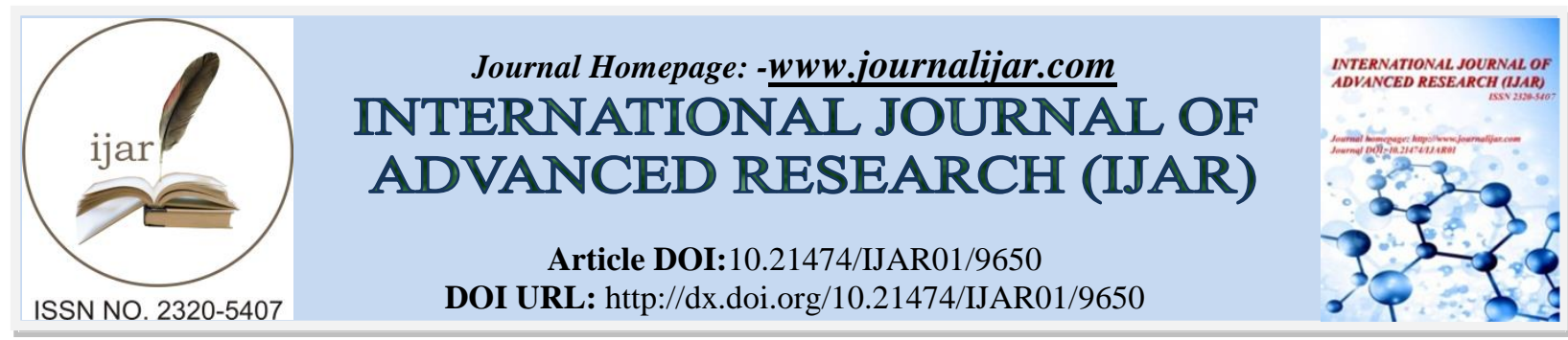

RESEARCH ARTICLE

\title{
NUTRIENT AND SELECTED PHYTOCHEMICAL COMPOSITIONS OF CASHEW NUT ( ANACARDUM OCCIDENTALE) AND GROUNDNUT ( ARACHIS HYPOGAEA ) SEED PASTES.
}

Prince N. Okoroh ${ }^{1}$ and Samuel C. Onuoha ${ }^{2}$.

1. Department of Biochemistry, College of Natural and Applied Sciences, Gregory University, Uturu, PMB 1012, AbiaState, Nigeria.

2. Department of Biochemistry, Faculty of Science, University of Port Harcourt ,PMB 5323 ,Port Harcourt , Nigeria.

\section{Manuscript Info}

(..........................

Manuscript History

Received: 04 July 2019

Final Accepted: 06 August 2019

Published: September 2019

Key words:-

Nutrient composition, Arachis hypogaea seeds ,Anarcadum occidantale seeds, selected phytochemical

\section{Abstract}

The proximate composition, calorific value, phytochemical composition and mineral concentrations of fried seeds (peeled and unpeeled) of Arachis hypogaea and Anacardum occidentale were investigated using standard methods. Moisture content was highest $(5.89 \pm 0.042 \%)$ in Anacardum occidentale unpeeled fried seeds (AOUFS) and lowest $(4.81 \pm 0.014 \%)$ in Arachis hypogaea peeled fried seeds (AHPFS) while ash ranged from $2.72 \pm 0.106 \%$ in Arachis hypogaea peeled fried seeds to $4.89 \pm 0.035 \%$ in Anacardum occidentale unpeeled fried seeds. Crude protein was highest $(27.27 \pm 0.106 \%)$ in Anacardum occidentale unpeeled fried seeds and lowest $(25.73 \pm 0.042 \%)$ in Arachis hypogea peeled fried seeds. Anacardumoccidentale unpeeled fried seeds had the highest $(6.44 \pm 0.056 \%)$ crude fibre, followed by Arachis hypogaea unpeeled fried seeds $(4.51 \pm 0.014 \%)$ but the values in the four samples analysed were significantly different $(\mathrm{p}<0.05)$. Crude fat was predominant in all the samples and the values were significantly $(\mathrm{p}<0.05)$ different. Anacardum occidentale peeled fried seeds had the highest (20.26 $\pm 0.028 \%)$ carbohydrate and Arachis hypogaea unpeeled fried seeds the lowest value $(10.61 \pm 0.056 \%)$ but the calorific values of all the four samples were significantly different $(p<0.05)$. All the processed seeds were found to be good sources of magnesium, potassium and calcium with appreciable levels of zinc and iron. Tannins and alkaloids were highest in Anacardum occidentale unpeeled fried seeds and lowest in Arachishypogaea peeled fried seeds but the levels of flavonoids were significantly different $(\mathrm{p}<0.05)$ in all the samples. Results highlighted in this study revealed that all the processed samples of both Arachis hypogaea and Anacardum occidentale had good nutritional and phytochemical potential and suggest their possible use in meeting human nutritional requirements, animal feed and medicinal formulations.

Copy Right, IJAR, 2019,. All rights reserved.

Corresponding Author:-Prince N. Okoroh.

Address:-Department of Biochemistry, College of Natural and Applied Sciences, Gregory University, Uturu, PMB 1012, AbiaState, Nigeria. 


\section{Introduction:-}

Food, nutrition and health have biochemical link and they affect the economic and social development of any nation (1). The local resources within the reach of the people could be harnessed in order to satisfy the needs of the increasing population of the world particularly, in developing nations like Nigeria (2).

Nuts,seeds and pulses have been reported (3), to be nutrient dense foods and since pre-agricultural periods, they have been the major constituents of the diet of humans. According to Dreheret al.,(4) and sabate'(5), nuts have been eaten by developed and developing nations in form of snacks, desserts, or part of a meal and are consumed whole whether fresh or roasted, in spreads such as peanut butter, as oils or hidden in marketed products ,mixed dishes, sauces, pastries, ice creams and baked foods. They have been assumed as an essential part of optimal diets for the prevention of CHD by leading experts in the field (6). Infact, nuts have been seen to possess wide-ranging cardiovascular and metabolic benefits, which can be readily incorporated with healthy diet (7). According to epidemiologic studies and clinical trials regular eating of nuts contribute to weight loss. In 2003, the US food and drug administration claimed (health wise) that when eaten could lead to reduced risk of CHD as well as blood cholesterol level (8). (9) and (10), since that time, highlighted that nuts have become an indispensable component of healthy foods, hence they are included in the American heart association dietary metrics for defining ideal cardiovascular health in their recent report on setting goals for health promotion and disease reduction for 2020

According to Ros (7), nuts are one of the natural plant foods richest in fat after vegetable oils but their fatty acid composition tend more towards monounsaturated and polyunsaturated fatty acids than saturated fatty acids. They are rich in protein and contain high levels of L-arginine (11) -a precursor of nitric oxide (an endogenous vasodilator). They contain folates, minerals, vitamin B-complex (12) , antioxidant vitamins (tocopherols) and phenolic compounds (13), they are cholesterol free but contain plant sterols which play essential roles in bio membranes (14). Ros (7) reported that the inclusion of nuts in a healthy dietary pattern will extend the cardio protective effect beyond those attributable to the components of any healthy diet exclusive of nut. Hu and Willet (6) also indicated that healthy dietary pattern is high in nut, vegetables, fruits, legumes, whole grains and lean protein sources and low fat dairy products. Since there is a link between cardiovascular events and development of other prevalent chronic disorders, including diabetes, cancer and neurodegenerative diseases, and supplementation of healthy diets with one daily serving of nuts could prevent these diseases (15).

Today, there is urgent need to find new products based on resources of biological origin and market them as they could be useful in making of food supplements, drugs and animal feeds(16). The study on the nutritional and therapeutic values of processed tropical nuts is very vital because people will be encouraged via scientific information from the research to consume greater quantity of foods rich in nuts prepared in different forms which will eventually provide them with a better balance of nutrients to enhance health status. Recently, researchers all over the globe have indicated more interest to evaluate locally processed nuts (wild and domesticated) for their nutritional, phytochemical as well as other features for the well-being of human society. The research was aimed at determining the nutritional value and accessing the nutraceutical potential of locally processed tropical nuts: Arachis hypogaea and Anacardum occidentale.

\section{Materials And Methods:-}

\section{Sample Collection and processing:}

The nuts studied were those of Arachis hypogaea and Anacardum occidentale. They were purchased from a local farm at Uturu in Isiukwuato Local Government Area of AbiaState. The nuts were selected, washed with clean water, fried and then separated into peeled and unpeeled samples. They were grinded to paste, and stored in labelled air tight containers, kept in refrigerator for analysis on dry weight basis.

\footnotetext{
Analysis of Sample:

The methods of the Association of Official Analytical Chemists (17) were used to determine the moisture content, ash, crude protein, crude fibre and crude fat. For moisture, two grams [2g] of each sample was accurately weighed in a chemical balance and placed in a crucible with lid and dried in an oven (Plus II Sanyo Gallenkamp PLC England) set at $105^{\circ} \mathrm{C}$ for $3 \mathrm{hr}$, until a constant weight was obtained after cooling. The loss in weight was expressed as a percentage of the initial weight. For ash, $2 \mathrm{~g}$ of each sample were weighed accurately into a porcelain crucible and ignited in a muffle furnace (Model LMF4 from Carbolite, Bamford, and Sheffield, England) at $550^{\circ} \mathrm{C}$ until a light grey ash was obtained after 7 hours. To determine crude fat, $9 \mathrm{~g}$ of the ground sample were transferred into a thimble and dried for $3 \mathrm{hrs}$ at $100^{\circ} \mathrm{C}$. The extraction thimble containing the dried samples was in turn inserted into the
} 
extraction chamber. The extraction and its contents were fixed to a pre-weighed empty round bottomed flask which was in turn placed over an electro- thermal heater. Then $300 \mathrm{ml}$ of anhydrous diethyl ether was added and the condenser was fixed. The sample was then extracted for $6 \mathrm{hrs}$, after which the solvent was distilled off, leaving the lipid in the flask to cool in a desiccator.

For crude fibre, $2 \mathrm{~g}$ of the ground sample [in triplicate] were transferred into the crucible and dried for $3 \mathrm{hrs}$ at $100^{\circ} \mathrm{C}$. The dried samples were defatted by extraction with $10 \mathrm{ml}$ of petroleum ether $\left(60-80^{\circ} \mathrm{C}\right)$, and air dried. The defatted sample was transferred into $100 \mathrm{ml}$ conical flask into which $20 \mathrm{ml}$ of $1.25 \% \mathrm{H}_{2} \mathrm{SO}_{4}$ was added and mixed properly. An aliquot $(190 \mathrm{ml})$ of boiling $\mathrm{H}_{2} \mathrm{SO}_{4}$ was added into the flask and mixed properly such that a cream was produced. This flask was fitted to a reflux condenser and heated before its content was rapidly poured into shallow layer of hot water contained in a hot Buchner funnel prepared with a wet $12.5 \mathrm{~cm}$ filter paper. Filtration was done by suction and the rate of suction adjusted such that filtration was complete within 10mins. The residue was washed free of acid with hot distilled water and quantitatively transferred into $100 \mathrm{ml}$ volumetric flask using $200 \mathrm{ml}$ of boiling $1.25 \%$ $\mathrm{NaOH}$ solution. Refluxing was done for 30mins and the filtrate was allowed to cool for a minute and filtered under suction. The residue was washed with several portions of boiling distilledwater followed by $1 \% \mathrm{HCl}$, finally with boiling distilled water until an acid free residue was obtained. The residue was quantitatively and carefully transferred [using a clean spatula] into a weighed crucible, which was dried in an oven at $105^{\circ} \mathrm{C}$ for $1 \mathrm{hr}$. Then, it was cooled in a desiccator and weighed. The dry residue was then placed in a furnace at $630^{\circ} \mathrm{C}$ for $3 \mathrm{hrs}$. The crude fibre content was calculated as well as the percentage crude fiber. The weight of ash was subtracted from that of the residue to obtain the weight of fibre. Crude protein (\%Nitrogen x 6.250 was obtained by the method of AOAC (17) using 2.0gportionsof the sample. The total carbohydrate content of the samples was determined by the difference method. The sum of the percentages of protein, fat, fibre and moisture was determined and the value subtracted from $100 \%$ to get the value for total carbohydrate (18). The energy values were estimated by the Atwater factors of 4,9 and 4 respectively, taking the sum of the products and expressing the results in kilocalories per 100g sample (18) and (19). The minerals magnesium,calcium, potassium, zinc and iron were determined by atomic absorption spectrophotometry as described by AOAC (17). Tannins, alkaloids, flavonoids, phytates and hydrocyanic acid were determined according to the method of AOAC (17). Saponins was determined by the method of (20)

\section{Data Analysis:}

Data were statistically analyzed by a one-way analysis of variance (ANOVA) using SPSS/PC + package. Differences between means were compared by Duncan's (21) Multiple Range Test. Significance was accepted at a $\mathrm{p}$-value of less than $0.05(\mathrm{p}<0.05)$.

\section{Results and Discussions:-}

The results of the proximate composition and calorific values of heat processed seeds (unpeeled and peeled) of Arachis hypogaea andAnacardum occidentale are shown in Table 1. Moisture content was highest in Anacardum occidentale unpeeled fried seeds (AOUFS) and lowest in Arachis hypogaea peeled fried seeds (AHPFS) but the values for Arachis hypogea unpeeled fried seeds (AHUFS) andAnacardum occidentale peeled fried seeds (AOPFS) were not significantly different ( $\mathrm{p}>0.5$ ). The moisture content of AHPFS and AHUFS as well as those of AOUFS and AOPFS were significantly different $(\mathrm{p}<0.05)$ respectively. The findings of this study indicated that moisture content ranged from $5.891 \%$ (AOUFS) to $4.811 \%$ (AHPFS) on dry wet basis (Table 3.1). The values highlighted in this study were lower than the moisture content of Crescentia cujeteleaves on dry weight basis (22), moisture content of dried mushrooms ( $P$. ostreatus) reported by (23) moisture content of boiled seeds of A. hypogaea (24) but higher than the value of moisture in fried seeds of A. hypogaea (24). According to (25), the amount of water in foods is a measure of water activity and water activity could be employed to measure how stable and susceptible that food substances could be when microorganisms want to contaminate them (26). Frying makes the samples stay longer and enhances their shelf life because it reduces their moisture content.

Dry matter was highest in AHPFS and lowest in AOUFS and the values were significantly different $(\mathrm{p}<0.05)$ but there was no significant difference $(\mathrm{p}>0.05)$ between the dry matter (DM) content of AHUFA and AOPFS.

AHPFS had the lowest ash content while AOUFS presented the highest value but there was no significant difference ( $\mathrm{p}>0.05$ ) between the values of AHUFS and AOPFS. The ash content of the unpeeled samples of fried A. hypogaea and $A$. occidentale were appreciable in this study compared to the low value of ash in AHPFS. The value of ash in fried seeds of A. hypogaea (24) was in consonant with the values obtained this study but the values in all other samples analysed was higher than the values reported for raw seeds and boiled seeds of A. hypogaea (24). (23) 
and(22) reported higher values of ash for P. ostretus and C.cujete dry leaves. Ash content reflects the mineral values of the nut samples analysed.

AOUFS had the highest protein content followed by AOPFS and then AHUFS followed by AHPFS but the crude protein content of AHUFS and AOPFS were not $(p>0.05)$ significantly different. The crude protein content of AHPFS and AHUFS, AOUFS and AOPFS were all significantly $(\mathrm{p}<0.05)$ different. The crude protein content of all the samples analysed was quite high indicating that they are very rich in plant protein but the protein values reported by (24) for heat processed seed pastes of A. hypogaea, (22) for dried leaves of C.cujete and (23) for samples of organically supplemented $P$. ostreatusanalysed on dry weight basis was higher. This implies that both peeled and unpeeled fried samples of A. hypogea and Anacardum occidentale can be consumed by people as good sources of plant protein in their diets.

Anacardum occidentale unpeeled fried seeds presented the highest value of crude fat followed by Arachis hypogaea unpeeled fried seeds and then AOPFS but the crude fat content of AHPFS was the lowest. There was significant difference $(\mathrm{p}<0.05)$ between the crude fat values of peeled and unpeeled seeds of both fried tropical seeds analysed. The fat contents of all fried samples of A. occidentale and A. hypogaea were high. (22) Reported low value of crude fat for C.cujete leaves and the values of raw and heat processed seed pastes of A. hypogaea reported by (24) were comparable. (23), (27) and (28), highlighted low fat content in their respective studies for $P$. ostreatussamples,P.citrinopilaetus and G. lucidum respectively. According to ROS (7), nuts are one of the natural plant foods richest in fat after vegetable oils but their fatty acid composition tend more towards monounsaturated and polyunsaturated fatty acids than the saturated counter parts. They have been assumed as an essential part of optimal diets for the prevention of CHD by leading experts in the field (6).

AOPFS had the highest carbohydrate content followed by AHPFS but the values of AHPFS, AHUFS, AOUFS and AOPFS were significantly different $(\mathrm{p}<0.05)$.

Unpeeled fried seeds of Anacardum occidentale presented the highest calorific value while unpeeled fried seeds of Arachis hypogaea presented the lowest value of energy.

AOUFS had the higest value of crude fibre (6.44 \pm 0.056$)$ followed by AHUFS $(4.51 \pm 0.014)$ while the values of AOPFS and AHPFS were lower although all the values were significantly $(\mathrm{p}<0.05)$. It is quite intresting to note that the crude fibre contents of AOUFS and AHUFS were higher than the values of AOPFS and AHPFS reported in this study. This result may be attributed to the fibre levels of the peels attached to the seeds unlike their peeled counter parts .Fibre consists of non-nutrient substances such as lignin and cellulose as well as cell wall polymers which cannot be digested by humans. Fibre helps to clean the intestinal tract and maintains peristaltic movement (29). It lowers glucose absorption in the digestive tract and removes cholesterol. Fibre helps to maintain bulk (30). The appreciable levels of fibre in these samples indicate that they can be consumed in the diet for diabetic patients and those suffering from obesity (for weight loss).

On dry weight basis, the total carbohydrate of the two samples of A. hypogaea and the two samples of A. occidentale varied from $10.611 \%$ to $20.261 \%$ as reported in this study (Table 3.1). However, the values highlighted for boiled seeds and fried seeds of A. hypogaeawere higher (24) . (22) Also reported higher value of total carbohydrate in $C$. cujete.

The calorific values reported in this study were comparable to the values indicated by (24) in their study for raw and heat processed seed pastes of A.hypogaea. The high energy values of all the samples analysed could be attributed to the high fat, crude protein and carbohydrate content of the samples. They may therefore serve as good sources of energy for patients sufferings from Protein Energy Malnutrition (PEM). Groundnut is very high in energy due to its high fat and protein content (31). (32) Reported that groundnut can be used to fight malnutrition during famine and World Health Organisation, UNICEF, Project Peanut Butter, and Doctors without Borders have used the products to help save malnourished children in developing nations. It can equally be used to make lactose free milk like beverage, which is now promoted in Africa as a way to reduce malnutrition among children (33).

The results of the quantitative phytochemical composition of heat processed seeds of A. hypogea (AHPFS, AHUFS), A. occidentale (AOUFS, AOPFS) respectively are shown in Table 2 Tannin value was highest in AOUFS $(1.75 \pm 0.091 \mathrm{mg} / 100 \mathrm{~g})$ and lowest in AHPFS $(1.21 \pm 0.021 \mathrm{mg} / 100 \mathrm{~g})$ but there was no significant difference $(\mathrm{p}>0.05)$ 
between tannin content of AHUFS and AOPFS. The flavonoid content in the samples was in order (highest to lowest): AOPES (3.84 $\pm 0.014 \mathrm{mg} / 100 \mathrm{~g})$, AOUFS $(3.44 \pm 0.035 \mathrm{mg} / 100 \mathrm{~g})$, AHUFS $(2.52 \pm 0.106 \mathrm{mg} / 100 \mathrm{~g})$ and AHPFS $(1.93 \pm 0.021 \mathrm{mg} / 100 \mathrm{~g})$ respectively but the values in each sample were significantly $(\mathrm{p}<0.05)$ different. Alkaloid level was highest in AOUFS $(2.80 \pm 0.035 \mathrm{mg} / 100 \mathrm{~g})$ followed by AOPFS $(1.67 \pm 0.028 \mathrm{mg} / 100 \mathrm{~g}) \mathrm{but}$ there was no significant difference between alkaloid content of AHPFS and AHUFS ( $>>0.05)$. Hydrocyanic acid was highest in AOUFS and lowest in AHPFS but all the values in the sample were significantly different ( $\mathrm{p}<0.05$ ). AHPFS had the lowest value of phytate while AOUFS had the highest level. There was significant difference between the phytate content of all the samples .Tannin composition was highest in unpeeled and peeled Anacardum occidentale compared to their A. hypogaea counterparts. The range of alkaloid and flavonoid in all the samples were appreciable. (23)Also reported that organically supplemented mushrooms are rich in alkaloids and flavonoids but lacked tannin while (22) reported appreciable level of alkaloids, flavonoids and tannins in dried leaves of $C$. cujete. Nuts with shell are rich in phytochemicals such as polyphenols (34). The medicinal properties of these seeds may be attributed to the presence of these bioactive compounds. These processed nuts may therefore be employed in the prevention, treatment and management of certain degenerative diseases. The higher levels of phytate and hydro cyanide in the unpeeled samples compared to the peeled samples could be due to the presence of these anti nutrients in their shells and seed coat.

The results of the mineral concentrations of heat processed seeds (unpeeled and peeled) of Arachis hypogaea and Anacardum occidentale are shown in Table 3. Magnesium was highest in AOUFS $(29.77 \pm 0.388 \mathrm{mg} / 100 \mathrm{~g})$ and lowest in AHPFS $(18.53 \pm 0.113 \mathrm{mg} / 100 \mathrm{~g})$. The magnesium concentration in all the samples was significantly different $(\mathrm{p}<0.05)$. Potassium presented the highest level amongst the minerals analysed. Potassium level was lowest in AHPFS and highest in AOUFS but there was significant difference between content of all the samples $(\mathrm{p}<0.05)$. The calcium levels of the samples (from highest to lowest) were in the order: AOUFS $(26 \pm 0.03 \mathrm{mg} / 100 \mathrm{~g})$, AOPFS $(35.39 \pm 0.014 \mathrm{mg} / 100 \mathrm{~g})$, AHUFS $(29.56 \pm 0.056 \mathrm{mg} / 100 \mathrm{~g})$, AHPFS $(28.46 \pm 0.021 \mathrm{mg} / 100 \mathrm{~g})$ respectively. The value of calcium in all the samples was significantly different $(\mathrm{p}<0.05)$. Zinc presented highest value in AOUFS and lowest value in AHPFS but the level of zinc in AHUFS and AHPFS were not significantly different $(p>0.05)$. The concentration of iron was highest in AHUFS followed by AHPFS and the values were significantly $(\mathrm{p}<0.05$ ) different. There was also no significant difference ( $p>0.05$ ) between the iron samples in AOUFS and AOPES respectively. The higher levels of phytate and hydro cyanide in the unpeeled samples compared to the peeled samples could be due to the presence of these anti nutrients in their shells and seed coat. Potassium concentration ranged from $36.83 \mathrm{mg} / 100 \mathrm{~g}$ to $52.41 \mathrm{mg} / 100 \mathrm{~g}$ in all the samples (AHPFS, AHUFS, AOPFS and AOUFS) on dry weight basis indicating that the potassium values of all the processed seed samples analysed were all high. (23) Reported higher values for potassium in samples of $P$. ostreatus cultivated by organic supplementation methods and (22) also reported a higher value for potassium in $C$. cujete dried leaves. Potassium is an essential macro mineral needed by the body to meet balanced ion Biochemistry. All cells use it as a major intracellular ion because it helps to keep the mineral balance in their cells (35). The potential difference created by potassium and sodium across the cell membrane helps in muscle contraction, neuronal transmission as well as normal function of the heart and associated vascular system (35). Since the fried seeds contain high levels of potassium, they may be used to prevent hypertension because diets with very low potassium levels (36) may cause high blood pressure.

Magnesium level ranged from $29.77 \mathrm{mg} / 100 \mathrm{~g}$ to $18.53 \mathrm{mg} / 100 \mathrm{~g}$ on dry weight basis in all the processed samples reported in this study. The values reported by (23) in their study for samples of $P$. ostreatus were lower but the value highlighted by (22) for $C$. cujete leaves on dry weight basis was much higher. Magnesium is vital as a cofactor in metabolism. It also plays great role in neuromuscular activities as well as actions in organs and system connected with heart and its associated vessels (37). Magnesium helps to make bio membrane permeable (38).

The samples had appreciable levels of calcium and the values reported in this study were comparable to the $P$. ostreatussample analysed by (23) but the level of calcium reported by (22) for C. cujete leaves on dry weight basis was higher. Calcium is vital in cell function and chemistry. It is needed in signal transduction, muscle contraction, fertilization as well as transmission along the nerve. It does the work of a second messenger (39). A lot of enzymes use calcium as a cofactor, it is needed in bone and teeth formation and calcium from the extracellular fluid helps to establish electrical pressure difference across cell membrane in an excited state (39).

The iron content of the samples as well as their zinc content were in consonant with the values reported by (24) in their study for raw and processed seeds pastes of A. hypogea but (23) and (22) highlighted higher values of iron and zinc in samples of $P$. ostreatus and $C$. cujete leaves that they studied, respectively. 
Table 1:-Proximate composition (\%) and calorific values of heat processed seeds (unpeeled and peeled) of Arachis hypogea and Anacardum occidentale.

\begin{tabular}{|c|c|c|c|c|}
\hline Composition(\%) & AHPFS* & AHUFS* & AOUFS* & AOPFS* \\
\hline Moisture content & $4.81 \pm 0.014^{c}$ & $5.54 \pm 0.84^{b}$ & $5.89 \pm 0.042^{a}$ & $5.63 \pm 0.021^{b}$ \\
\hline Dry matter & $95.19 \pm 0.014^{a}$ & $94.46 \pm 0.084^{b}$ & $94.11 \pm 0.042^{c}$ & $94.41 \pm 0.049^{b}$ \\
\hline Ash & $2.72 \pm 0.106^{c}$ & $4.31 \pm 0.049^{b}$ & $4.89 \pm 0.035^{a}$ & $3.74 \pm 0.056^{b}$ \\
\hline Crude protein & $25.73 \pm 0.042^{c}$ & $26.74 \pm 0.134^{b}$ & $27.27 \pm 0.106^{a}$ & $26.90 \pm 0.148^{b}$ \\
\hline Crude fiber & $2.80 \pm 0.028^{d}$ & $4.51 \pm 0.014^{b}$ & $6.44 \pm 0.056^{a}$ & $3.72 \pm 0.021^{c}$ \\
\hline Fat & $46.28 \pm 0.056^{b}$ & $48.28 \pm 0.169^{a}$ & $40.25 \pm 0.063^{c+}$ & $39.73 \pm 0.021^{d}$ \\
\hline Carbohydrate & $17.65 \pm 0.134^{b}$ & $10.61 \pm 0.056^{d}$ & $15.24 \pm 0.021^{c}$ & $20.26 \pm 0.028^{a}$ \\
\hline Calorific value & $590.04 \pm 0.050^{a}$ & $511.65 \pm 0.010^{d}$ & $532.29 \pm 0.4005^{c}$ & $546.21 \pm 0.035^{b}$ \\
\hline (kcal/100g sampl & & & & \\
\hline
\end{tabular}

1. Values are Means \pm standard deviation of triplicate determination. Values in the same row having the same superscript letters are not significantly different $(\mathrm{p}>0.05)$.

2. AHPFS=A. hypogaea peeled fried seeds.

3. AHUFS=A. hypogaea unpeeled fried seeds.

4. AOUFS=Anacardumoccidentale unpeeled fried seeds.

5. AOPFS=Anacardumoccidentale peeled fried seeds.

Table 3.2:-Phytochemical composition $(\mathrm{Mg} / 100 \mathrm{~g})$ of heat processed seeds (unpeeled and peeled) of Arachis hypogea and Anacardum occidentale.

\begin{tabular}{|c|c|c|c|c|}
\hline Parameter (Mg/100g) & AHPFS & AHUFS & AOUFS & AOPFS \\
\hline Tannin & $1.21 \pm 0.021^{\mathrm{c}}$ & $1.52 \pm 0.106^{b}$ & $1.75 \pm 0.091^{\mathrm{a}}$ & $1.66 \pm 0.028^{b}$ \\
\hline Alkaloid & $1.36 \pm 0.028^{c}$ & $1.43 \pm 0.021^{c}$ & $2.80 \pm 0.035^{a}$ & $1.67 \pm 0.028$ \\
\hline Hydro cyanide & $1.81 \pm 0.021^{d}$ & $2.79 \pm 0.042^{b}$ & $3.22 \pm 0.028^{a}$ & $2.46 \pm 0.021^{c}$ \\
\hline Phytate & $0.83 \pm 0.014^{d}$ & $1.04 \pm 0.007^{d}$ & $1.52 \pm 0.106^{\mathrm{a}}$ & $1.31 \pm 0.035^{b}$ \\
\hline
\end{tabular}

* Values are Means \pm standard deviation of triplicate determination. Values in the same superscript letters are not significantly different $(\mathrm{p}>0.05)$.

*AHPFS=A. hypogaea peeled fried seeds.

*AHUFS=A. hypogaea unpeeled fried seeds.

*AOUFS=Anacardum occidentale unpeeled fried seeds.

*AOPFS=Anacardum occidentale peeled fried seeds. 
Table 3:-Mineral concentration (mg / $100 \mathrm{~g}$ ) of heat processed seeds (unpeeled and peeled) of Arachis hypogaea and Anacardum occidentale.

\begin{tabular}{ccccc}
\hline Analyte & AHPFS & AHUFS & AOUFS & AOPFS \\
\hline Magnesium & $18.53 \pm 0.113^{\mathrm{d}}$ & $21.70 \pm 0.028^{\mathrm{c}}$ & $29.77 \pm 0.388^{\mathrm{a}}$ & $28.38 \pm 0.021^{\mathrm{b}}$ \\
Potassium & $36.83 \pm 0.014^{\mathrm{d}}$ & $40.80 \pm 0.000^{\mathrm{c}}$ & $52.41 \pm 0.021^{\mathrm{a}}$ & $49.28 \pm 0.020^{\mathrm{b}}$ \\
Zinc & $0.70 \pm 0.021^{\mathrm{c}}$ & $0.76 \pm 0.021^{\mathrm{c}}$ & $1.28 \pm 0.049^{\mathrm{a}}$ & $1.15 \pm 0.007^{\mathrm{b}}$ \\
Iron & $1.07 \pm 0.021^{\mathrm{a}}$ & $1.16 \pm 0.042^{\mathrm{a}}$ & $0.89 \pm 0.035^{\mathrm{b}}$ & $0.85 \pm 0.106^{\mathrm{b}}$ \\
Calcium & $28.46 \pm 0.021^{\mathrm{d}}$ & $29.56 \pm 0.056^{\mathrm{c}}$ & $36.26 \pm 0.035^{\mathrm{a}}$ & $35.39 \pm 0.014^{\mathrm{b}}$ \\
\hline
\end{tabular}

* Values are Means \pm standard deviation of triplicate determination. Values in the same superscript letters are not significantly different $(\mathrm{p}<0.05)$.

*AHPFS $=$ A. hypogaea peeled fried seeds.

*AHUFS $=A$. hypogaea unpeeled fried seeds.

*AOUFS=Anacardum occidentale unpeeled fried seeds.

*AOPFS=Anacardum occidentale peeled fried seeds.

\section{Conclusion:-}

The results from this study showed that fried Arachis hypogea (unpeeled and peeled) and Anacardum occidentale (unpeeled and peeled) are rich in crude protein, fat, energy and minerals such as magnesium, potassium and calcium but contain appreciable levels of fibre, ash and trace minerals such as zinc and iron. These results therefore showed the nutritional potential of both the peeled and unpeeled samples of these fried seeds and suggest their possible use in food to meet nutritional needs in humans and livestock feed supplements. The results from this study also showed the nutraceutical potential of the processed samples of A. hypogaea and A. occidentale having appreciable levels of phytochemicals such as alkaloid, flavonoid and tannin, suggesting their possible use as medicinal supplements.

\section{Acknowledgements:-}

The authors thank the head and the entire staff of Biochemistry research unit, Gregory University,Uturu,Abia State, Nigeria, for their immense support geared towards achieving this scholarly research work.

\section{Competing interests}

The authors hereby declare that there was no conflict of interest or financial inducement which may have negatively influenced them in writing this scholarly article

\section{References:-}

1. Atasie, V. N., Akinhanmi, J.F and Ojiodu, C.C., (2009). Proximate analysis and physico-chemical properties of groundnut (Arachishypogaea L.): Pakistan Journal of Nutrition,8: 194-197.

2. Achu, B.M., Fokou, E., Tchiegang, C., Fosto,M. and Tchouanguep, F.M (2000). Nutritive value of some Cucurbitaceae oil seeds from different regions in cameroon. African Journal of Biotechnology, 4: 1329-1334.

3. Eaton, S.B, and Konner, M. (1985) Paleolithic nutrition. A consideration of its nature and current implications. New England Journal Medicine312: 283-289.

4. Dreher, M.L, Maher, C.V and Kearney, P.(1996). The traditional and emerging role of nuts in healthful diets. Nutriton Review54: 241-245.

5. Sabate, J. ( 1999). Nut consumption, vegetarian diets, ischemic heart disease risk, and all - cause mortality : evidence from epidemiologic studies. American Journal of Clinical Nutrition70 : $500 \mathrm{~S}-503 \mathrm{~S}$

6. Hu, F. B. and Willet, W. C. (2002) Optimal diets for prevention of coronary heart disease. Journal of American Medical Association. 288: 2569-2578.

7. Ros, E. (2010). Health benefits of nut consumption. Nutrients.2(7): 652-682. 
8. US Food and Drug Administration (2003). Qualified Health Claims, Letter of Enforcement Discertion- Nuts and Coronary Heart Disease. US Food and Drug Administration; Rockville, MD, USA, pp. 1-4.

9. King, J.C., Blumberg, J., Ingwesern, L., Jenab, M. and Tucker, K.L. (2008). The nuts and peanuts as components of a healthy diet. Journal of Nutrition.138: 1736- 1740.

10. Nash, S.D. and Nash, D.T. (2008). Nuts as part of a healthy cardiovascular diet. Current Atherosclerosis Review.10: 529-535.

11. Brafan, G., Boatella, J. and Rafecas, M (2006). Nuts, source of energy and macronutrients. British Journal of Nutrition. 96: 524-528.

12. Welch, G.N and Loscalzo, J. (1998) Homocyte and atherothrombosis. New England Journal of Medicine 338: 1042-1050.

13. Blomhoff, R., Carlsen, M.H. Frost Anderson, L. and Jacobs, D. R. Jr, (2006). Health benefits of nuts potential role of antioxidents. British Journal of Nuttrion.96: 552-560.

14. Hartmann, M. A. (1998) Plant sterols and the environment. Trends Plant Science.3: 170- 175.

15. 15.Estruch, R., Martinez-Gonzàlez, M.A., Corella, D., Salas-Salvadó J., Ruiz-Guitiérrez, V., Covas, M.I., Fiol, M., Gômez-Gracia, E., Lōpez-Sabater, M.C., Vinyoles, E., Aros, F., Conde, M., Lahoz, C., Lapetra, J., Sáez, G. and Ros, E. (2006). Effects of a Mediterranean- style diet on cardiovascular risk factors. A randomised trial. Annals of Internal Medicine. 145: 1-11. On behalf of the PREDIMED Study Investigators.

16. Beattie, A.J., Hay, M., Magnusson, B., de Nys, R., Smeathers, J., and Vincent, J.F. (2011).’'Ecology and bioprospecting', Austral Ecology, 36 (3): 341-356.

17. AOAC (2006)International official methods of Analysis of theAOAC (W.Horwitiz Edition), 18th edn. Washington D.C., USA: AOAC international.

18. Onyeike , E. N. And Acheru , G. N. ( 2002 ) Chemical composition ofselected oil seeds and physiochemical properties of the oil extraction. Food Chemistry, 77: $431-437$.

19. Chaney, S.G.(2006).Principles of Nutrition II: Micronutrients in T.M. Devlin (Ed). Texrbook of Biohemistry with clinical correlations $6^{\text {th }}$ edn. (pp. 109-1120). New York: John Wiley and Sons.

20. Obadoni, B.O.andOchukoOchuko , P. O. (2001) Phytochemical studies of comparativeefficacy of crude extracts of some botanical plants in Edo and Delta States of Nigeria. Global Journal of Pure and Applied Science.WWW.academia.edu/1892967/phytochemical

21. Duncan ,D.B. (1955). Multiple range and multiple F tests. Biometrics 11: 1- 42

22. Olaniyi, M.B., Lawal, O.I and Olaniyi, A.A. (2018). Proximate, phytochemical screening and mineral analysis of Crescentia cujete L. leaves. Journal of Medicinal Plants for Economic Development. 2(1): 4-7.

23. Okoroh, P.N., Uwakwe, A.A., and Manago-Ighorodje, C.C. (2017) Proximate, Macroelement and trace mineral composition of the fruit bodies of pleurotusostreatus (Pleurotacea) cultivated by three substrate organic supplementation techniques. International Journal of Multidisciplinary Research, 3: 4-10.

24. Onyeike ,E.N. and Oguike , J.U.(2003).Influence of heat processing methods on the nutrient composition and lipid characterization of groundnut ( Arachishypogaea ) seed pastes . Biokemistri 15(1 ): $34-43$.

25. Olutiola, P.O., Famurewa, o., and Sonntag, H.G., (1991). An introduction to Microbiology. Approach to General Practical Heidelberger verlgsansatalt and DrukereiGMbH, Heidelberg, Federal Republic of Germany. Pp 267.

26. Uraih, N and Izuagbe, Y. 1990). Public Health Food and Industrial Microbiology: Nigeria: Uniben Press. ISBN: 978-2027-00-6.

27. Fredrick, M., Sheila, O., Richard, K.M., Stella, W and Knight, M. (2013).Proximate composition, amino acids and vitamins profile of pleurotuscitrinopileatussinger;An indigenous mushroom in Kenya. American Journal of Food Technology, 8: 200-206.

28. Sumaira, S., Ghulam, M., Hira, m., Connie, M.W., Yasir, K. and Muhammed, S. (2016). Mineral profile of wild Ganodermalucidum and four commercial excotic mushroom by ICP-OES and LIBS. Journal of Food and Nutritional Research. 4 (11): 703-708.

29. Mukhopadhyay, R. and Guha, A.K. (2015). “A comparative analysis of the nutritional quality of edible mushroom pleurotussajor-caju grown in deproteinized whey medium', LWT- Food Science and Technology, 61: 339-345.

30. Mathenge, L. (1997). Nutritional value and utilization of indigenous vegetables in Kenya. Jn: Guarino, L. (edn.)Traditional African Vegetable: proceedings of the IPGRI.

31. Elegbede, J.A (1998) Legumes in: Nutrional Quality of Plant Foods (Osagie, A.U. and Eka, O.U. eds) $1^{\text {st }}$ edn. Post-Harvest Research Unit, Department of Biochemistry, University of Benin, Benin City Nigeria, pp. 53-83. 
32. Seijo, G., Graciela,I.L. , Aveliano ,F., Krapovickas,Daniel,A.D, David, J.B. , Eduardo , A.M. ( 2007 ) Genomic relationships between The cultivated peanut ( Arachishypogaea ) and its close relatives revealed by double GISH.American Journal of Botany.94 ( 12):1963 - 1971

33. Food and Agricultural Organisation (1986) Compositional analysis methods. Manuals of food quality control. Food analysis: General techniques, additives, contaminants, and composition( Food and Agricultural Organisation of the United Nations ) Food and Nutrition Paper 14/ 7. Pp203 - 232.

34. Pohl, H.R., Wheeler, J.S and Murray, H.E (2013).'Chapter 2, Sodium and potassium in health and disease'. In Astrid sigel, Helmut sigel and Roland, K.O signel. Interrelations between essential metal ions and human diseases. Metal ions in life sciences 13. Springer. Pp. 29-47.

35. Mikko,H., Lars, S., Olle, E. (2006). 'A comparison between two prokaryotic potassium channels (KirBacl. I and KcsA) in a molecular dynamic (MD) simulation study' Biophysical Chemistry, 12(1): 1-9.

36. Aburto, N.J.M., Hanson, S., Gutierrez, H., Hopper, L., Elliot, P., and Cappuccio,F.P., (2013). 'Effect of increased potassium intake on cardiovascular risk factors and disease systematic review and meta-analysis. British Medical Journal 34(6):33-78.

37. Ryan, M.F. (1991). The role of magnesium in Clinical Biochemistry: an overview. Annals of Clinical Biochemistry, 128: 19-26.

38. Noronha, J.L.and Matuschak, G.M.(2002). Magnesium in critical illness:Metabolism,assessment and treatment. Intensive Care Medicine , 26 (6) : 667 - 679.

39. Brini, M., Ottolin, D., Catt, T, and Carafoli, E. (2013) 'Chapter 5 intracellular calcium homeostasis and signaling'. In Banci, Lucia (edn.). Metallomics and the cell, metal ions in life sciences. 12 springer pp 81-137. 